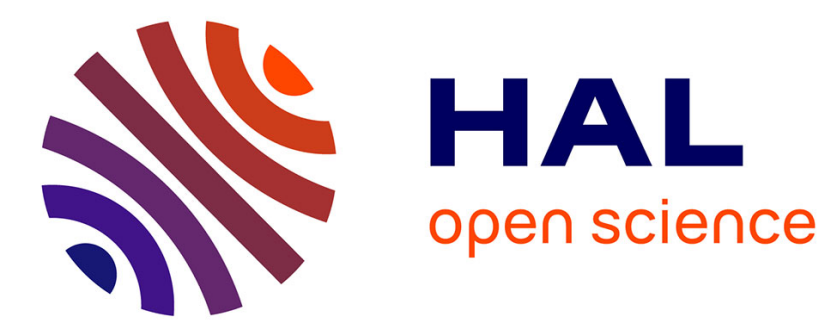

\title{
The influence of material properties on the amount of twist of spruce wood during kiln drying
}

\author{
A. Straže, R. Kliger, M. Johansson, Ž. Gorišek
}

\section{To cite this version:}

A. Straže, R. Kliger, M. Johansson, Ž. Gorišek. The influence of material properties on the amount of twist of spruce wood during kiln drying. European Journal of Wood and Wood Products, 2010, 69 (2), pp.239-246. 10.1007/s00107-010-0422-1 . hal-00594482

\section{HAL Id: hal-00594482 \\ https://hal.science/hal-00594482}

Submitted on 20 May 2011

HAL is a multi-disciplinary open access archive for the deposit and dissemination of scientific research documents, whether they are published or not. The documents may come from teaching and research institutions in France or abroad, or from public or private research centers.
L'archive ouverte pluridisciplinaire HAL, est destinée au dépôt et à la diffusion de documents scientifiques de niveau recherche, publiés ou non, émanant des établissements d'enseignement et de recherche français ou étrangers, des laboratoires publics ou privés. 


\title{
The influence of material properties on the amount of twist of spruce wood during kiln drying
}

\author{
A. Straže ${ }^{1 *}$, R. Kliger ${ }^{* *}$, M. Johansson ${ }^{* * *}$, Ž. Gorišek ${ }^{*}$ \\ *University of Ljubljana, Biotechnical Faculty, Department of Wood Science and \\ Technology, Rožna dolina, C. VIII/34, SI-1000 Ljubljana, Slovenia; Email ${ }^{\text {: }}$ \\ ales.straze@bf.uni-lj.si \\ **Chalmers University of Technology, Department of Structural Engineering, \\ Steel and Timber Structures, SE-41296 Göteborg, Sweden \\ ***Vaxjo University, School of Technology and Design, SE-35195 Vaxjo, Sweden
}

\begin{abstract}
The development of twist in Norway spruce boards (Picea abies Karst.) during normal temperature kiln drying was researched. Tangentially oriented boards were sawn from diametrical radial planks, from which the basic wood properties, i.e. linear shrinkage and grain angle, were determined. The unrestrained boards were kiln dried using a selected drying schedule. During the controlled drying process the moisture content (MC) and twist of the boards were measured. Twist was generally induced by the shrinkage of wood below the fibre saturation point, and increased in proportional to the decrease in MC. The earlier appearance of twist, with regard to $\mathrm{MC}$ and drying time, was confirmed in the case of boards sawn from the central part of logs. The final twist amounted to between 10 and $20 \% \mathrm{~m}$ in the case of boards close to the pith, and decreased to less than $4 \% \mathrm{~m}$ in the case of boards sawn at a radius of $70 \mathrm{~mm}$ from the centre of the logs. Ring curvature had the highest impact on the final twist of the dried boards, followed by grain angle and tangential shrinkage.
\end{abstract}

\section{Einfluss der Materialeigenschaften auf die Verdrehungen von Fichtenholz bei der technischen Trocknung}

\section{Zusammenfassung}

Untersucht wurde die Entwicklung der Verdrehung von Fichtenholz während der technischen Trocknung unter üblichen Temperaturen. Kernbohlen wurden in Bretter mit tangentialem Jahrringverlauf aufgetrennt und deren Eigenschaften, d. h. lineares Schwindmaß und Faserabweichung, wurden bestimmt. Die Proben wurden unbehindert gelagert und mit einem ausgewählten Trocknungsprogramm getrocknet. Während des Trocknungsverlaufes wurden die Holzfeuchte (MC) und die Verdrehung der Bretter gemessen. Die Verdrehung wurde im Allgemeinen durch Schwinden des Holzes unterhalb Fasersättigung verursacht und sie nahm mit abnehmender Holzfeuchte proportional zu. Die Bretter aus dem marknahen Bereich verdrehten sich früher, d. h. bei hoher Holzfeuchte und kürzerer Trocknungszeit. Am Ende betrug die Verdrehung bei marknahen Brettern 10 - 20 $\% / \mathrm{m}$, während Bretter mit einem Markabstand von $70 \mathrm{~mm}$ nur eine Verdrehung von $4 \% \mathrm{~m}$ aufwiesen. Den größten Einfluss auf die endgültige Verdrehung der getrockneten Bretter hatte der vom Markabstand abhängige Jahrringverlauf gefolgt von der Faserabweichung und dem tangentialen Schwindmaß. 


\section{Introduction}

\subsection{Background}

Warping, mainly twist, crook and bow, of the sawn wood of Norway spruce (Picea abies Karst.) frequently causes serious problems in the wood construction industry. Twist usually causes most severe problems leading to wood downgrading and increasing risk of substitution of wood with other engineering materials (Perstorper et al. 1995; Forsberg and Warensjö 2001).

The two material parameters most commonly associated with twist are grain angle (GA) and distance from the pith to the centre of the cross-section of the board, which is an indirect expression of the annual-ring curvature. The significance of these parameters was studied using some analytical models (Stevens and Johnston 1960; Booker 2005; Bäckström and Johansson 2006), as well as statistics from data on stationary conditioning experiments (Johansson et al. 2001; Warensjo and Rune 2004) and numerical modelling (Ormarsson et al. 1998). In most cases ring curvature was found to be the best predicting variable, or had the greatest impact on twist variation, followed by GA. Recently, an additional explanation of the twist of sawn wood has been presented, including the grain angle gradient (Forsberg and Warensjö 2001).

Much research was done in order to prevent twist of sawn wood during experimental and industrial drying. For this reason different drying schedules were studied at normal temperature varying the drying conditions (Milota 2000). Improved shape stability of dried sawn wood was achieved by additional steaming of boards, cyclically varying the climatic conditions during drying, or increasing the loads on top of kiln stacks (Mackay 1973; Arganbright et al. 1978; Kliger et al. 2005; Frühwald 2006). Many investigations on drying at high temperatures were made in order to improve the straightness and shape stability of structural timber (Pang et al. 2001; Thiam et al. 2002; Frühwald 2007).

In many cases, twist was studied as end result of wood drying procedures. However, fewer investigations on real time twist development were carried out in the laboratory or during semi-industrial drying, including the variability of properties of individual drying specimens. In such drying experiments, twist and torque usually increased in proportion to the reduction in moisture content (MC) (Mackay 1973; Sandland and Tronstad 2001; Gorišek et al. 2006; Gorišek and 
EJWWP422_source.doc

Straže 2005). Decrease in torque and twist was achieved by increasing the drying temperature and pre-steaming of the material prior to drying. The same relationship between torque and $\mathrm{MC}$ was confirmed in drying simulations using the finite element method (Ormarsson et al. 1999) and in static climatic conditioning (Bäckström and Kliger 2006).

\subsection{Aim}

The aim of this research was to analyse the real time development of unrestrained twisting in sawn wood made of Norway spruce (Picea abies Karst.) during conventional normal temperature kiln drying and, in particular to investigate the dependency of twist on basic wood properties such as grain angle, tangential shrinkage and growth ring curvature. An additional objective of the research was to produce a predictive model of unrestrained twist during kiln drying, applicable for process optimization.

This study is part of a research project on the variation of wood properties and comparison of juvenile and adult wood of Norway spruce (Picea abies Karst.) and Silver fir (Abies alba Mill.). A series of papers on the radial distribution of basic physical and mechanical properties of the used material and their interdependence has already been published (Straže and Gorišek 2000; Gorišek et al. 2004).

\section{Experimental}

\subsection{Material}

Ten Norway spruce trees, 50 to 70 years old, were randomly selected from a stand in the Slovenian Alps. Two successive logs, 0.4 and $0.9 \mathrm{~m}$ in length, were cut off at breast height from each individual tree. Basic wood properties were determined using the shorter logs, from which samples were sawn out in radial direction (Fig. 1) for tangential shrinkage and grain angle measurements. The longer logs were used for the preparation of 170 boards, 14 to 20 per log, which were examined in drying experiments.

\subsection{Determination of basic wood properties}

The oriented small specimens, with dimensions of $18 \mathrm{~mm} \times 18 \mathrm{~mm} \times 5 \mathrm{~mm}(\mathrm{rad}$. $\times$ tang. $\times$ long.), were cut out along the radial direction of the shorter logs, from pith to bark (Fig. 1). The specimens were measured by callipers having a 
EJWWP422_source.doc

precision of $0.01 \mathrm{~mm}$, and weighed with a precision of $0.001 \mathrm{~g}$, at five moisture content stages: 1 -green stage, 2, 3 and 4 - equilibrated at $20{ }^{\circ} \mathrm{C}$ and constant relative air humidity $\left(\mathrm{RH}_{2}=87 \%, \mathrm{RH}_{3}=65 \%, \mathrm{RH}_{4}=33 \%\right)$, and 5 - oven-dry stage. Moisture content was determined gravimetrically.

The tangential shrinkage strain $\varepsilon_{T}$ and the shrinkage coefficient $\alpha_{T}$ of the small specimens were determined in the quasi-linear hygroscopic range (Eq. 1, 2):

$$
\begin{aligned}
& \varepsilon_{T}=\frac{L_{2}-L_{4}}{L_{4}} \\
& \alpha_{T}=\left|\frac{\varepsilon_{T}}{M C_{2}-M C_{4}}\right|
\end{aligned}
$$

A linear regression model of actual tangential shrinkage based on total shrinkage strain $\left(\varepsilon_{\mathrm{T} 0} ; \mathrm{MC}=0 \%\right)$ and the shrinkage coefficient $\left(\alpha_{\mathrm{T}}\right)$, was additionally used to determine the shrinkage development. Tangential shrinkage onset was calculated from the intersection point between the model curve and the x-axis. This value was also used for assessment of the local fibre saturation point (FSP).

Remaining parts of the short logs were used to determine grain angle (GA). Thin tangentially oriented lamellas were sawn from radial planks at $6 \mathrm{~mm}$ intervals, from the pith to the bark. The grain angle was determined by hand cleaving of 350 $\mathrm{mm}$ long lamellas in the longitudinal-tangential (LT) plane determining the cleaving angle (Fig. 1) (Eq. 3):

$$
G A=\arctan \left(\frac{a-b}{c}\right),
$$

where:

$a, b=$ width of the cleaved lamella at both ends, $\mathrm{c}=350 \mathrm{~mm}$... length of lamella.

The $6 \mathrm{~mm}$ radial interval of the lamellas coincided with $18 \mathrm{~mm}$ thick boards used in the drying procedure. Therefore, each sequence of three lamellas has the same radial position with respect to parallel drying boards. The middle lamella in the bundle was thus used for assessment of the mean grain angle in the case of parallel drying board, whereas the first and the third lamella were used to predict the grain angle gradient ( $\mathrm{GA}_{\text {gradient }}$ (Eq. 4): 
EJWWP422_source.doc

$$
G A_{\text {gradient }}=\frac{G A_{1}-G A_{3}}{\Delta x},
$$

where:

$\mathrm{GA}_{1}, \mathrm{GA}_{3}=\mathrm{GA}$ of the outer lamellas in the bundle,

$\Delta \mathrm{x}=12 \mathrm{~mm}$...distance between the outer lamellas in the bundle.

\subsection{Drying procedure}

Diametrically radial planks were made from the longer logs $(1=0.9 \mathrm{~m})$, which were ripped through the pith and sawn radially into $18 \mathrm{~mm}$ thick, tangentiallyoriented drying boards (Fig. 1). A small slice was initially cut off from each drying board, and used for gravimetrical determination of its initial MC (Fig. 1). Extra watertight protective paint was used at both ends of each board in order to prevent rapid longitudinal water evaporation. Afterwards the unrestrained boards were kiln dried in a ladder-like wooden holder. Boards were freely supported at both ends with horizontal 20 by $20 \mathrm{~mm}$ stickers, and vertically spaced by $80 \mathrm{~mm}$. A conventional normal temperature drying schedule was used, with step-raised temperatures from 67 to $80{ }^{\circ} \mathrm{C}$ and an increasing drying gradient from 3.0 to 4.3 . The average moisture content of the boards during drying was determined gravimetrically at five intervals (Eq. 5):

$$
M C_{t}=\frac{m_{t}}{m_{i}}\left(M C_{i}-1\right)+1
$$

where:

$\mathrm{MC}_{\mathrm{t}}, \mathrm{MC}_{\mathrm{i}}=$ temporary and initial moisture content, $\mathrm{m}_{\mathrm{t}}, \mathrm{m}_{\mathrm{i}}=$ temporary and initial weight of drying board.

The same interval was used to determine twist of the dried boards. The amount of twist (TW) was measured by a wedge with a precision of $0.5 \mathrm{~mm}$, which was used to calculate the twist angle. Additionally, the relative twist (RTW) was recalculated at the end of the drying procedure (Eq. 6):

$$
R T W=\frac{T W_{t}}{T W_{j}},
$$

where:

$\mathrm{TW}_{\mathrm{t}}, \mathrm{TW}_{\mathrm{j}}=$ temporary and final twist of boards $\left[{ }^{\circ}\right]$ 


\section{Results and discussion}

\subsection{Variation of the relevant wood properties}

In general, the longitudinally aligned wood tissue deviated significantly from the tree axis. The grain angle was left-handed in the juvenile region of all the examined trees having, close to the pith, an average value of $4^{\circ}(\mathrm{CV}=27.2 \%$; $\mathrm{CV}$ $=$ coefficient of variation). As a rule, three typical radial gradients of the grain angle with the distance from the pith were observed: (1) insignificant decrease in GA or GA maintained a constant value, and the grain orientation remained lefthanded ( $\mathrm{n}=3 \operatorname{logs})$, (2) a medium-sized decrease in GA, where the grain orientation tended to become almost straight $(n=4 \operatorname{logs})$, and (3) a large decrease in GA, where the grain changed its orientation to right-handed ( $n=3 \operatorname{logs}$ ) (Fig. 2a). Consequently, a wider distribution of GA was determined in the case of boards located close to the logs' circumference $\left(\mathrm{GA}=0.7^{\circ} ; \mathrm{CV}=314 \%\right)$. An analysis of the GA gradient revealed higher values at locations close to the pith, i.e., $\pm 2.5 \% / \mathrm{cm}$. The GA gradient decreased with distance from the pith reaching nearly constant values of $\pm 1.5 \% / \mathrm{cm}$ already at a radius of $30 \mathrm{~mm}$ (Fig. 2b). These results are in good agreement with those of related studies on grain angle and other growth characteristics of Norway spruce wood (Danborg 1994; Forsberg and Warensjö 2001; Perstorper et al. 2001; Sepulveda 2001).

Shrinkage of the investigated material was similar to the one reported in literature. The overall mean tangential shrinkage coefficient was $0.34 \% / \%(\mathrm{CV}=11.7)$, with a significantly lower value, i.e., $0.30 \% / \%(p \leq 0.05)$, in the case of specimens located within $40 \mathrm{~mm}$ from the pith (Fig. 2c). The abnormal shrinkage of juvenile wood can be due to its diversity in the chemical composition, the cell wall structure, and the microfibril angle (Harris and Meylan 1965; Harris 1977; Donaldson and Burdon 1995). A small increase in tangential shrinkage with distance from the pith was also noted in studies by Cown and McCounchie (1983), Chong and Fogg (1989), and Perstorper et al. (2001), whereas the authors ascribe lower tangential shrinkage close to the pith to growth ring curvature. The closer to the pith the more tangential shrinkage is influenced by radial shrinkage, as a result of the measurement method.

Using the intersection point method, the mean FSP of the whole tested material was found to be $26.8 \%(\mathrm{CV}=11.4 \%)$. The mean FSP of the specimens positioned 
within $40 \mathrm{~mm}$ from the pith was $28.7 \%$, and had a low variability $(\mathrm{CV}=7.4 \%)$, whereas specimens located at a greater distance from the pith showed significantly lower FSP values. The lowest mean FSP, i.e., $26 \%(\mathrm{CV}=12.1 \%)$, was found at locations close to the circumference of the logs (Fig. 2d). It is worth mentioning that the wood density of the material examined in the research project had the opposite radial profile in comparison with the FSP, where the wood density increased from $390 \mathrm{~kg} / \mathrm{m}^{3}$, close to the pith, to $450 \mathrm{~kg} / \mathrm{m}^{3}$ next to the circumference of the logs (Straže and Gorišek 2000). This negative correlation between FSP and wood density was similarly confirmed by various experimental techniques on hardwood and softwood species (Vorreiter 1963; Feist and Tarkow 1967; Kellogg and Wangaard 1969). Stamm (1971) reported FSP values for North American softwoods ranging between 21 and 32\%, which were based on the sorption isotherm extrapolation method.

\subsection{Drying progress and development of twist}

The green moisture content of the boards varied significantly with regard to their radial position in the experimental logs. Generally, low green MC values, between 40 and $80 \%$, were determined in the central part of the logs. On the contrary, boards from the circumference of the logs had much higher green $\mathrm{MC}$, always above $100 \%$. The green MC state of the boards also had a strong impact on their drying kinetics. During drying, the central and intermediate boards reached a MC close to the fibre saturation point already within the first two days of the process, whereas at least twice the time was needed in the case of boards from the periphery (Fig. 3). Furthermore, because of the high green $\mathrm{MC}$ values, a higher MC gradient at the cross-section of the peripheral boards can be expected during the whole drying process.

Twisting of all the examined boards generally started around the fibre saturation point, and increased proportionally with $\mathrm{MC}$ reduction to the highest values at the end of drying (Fig. 3). Closer analysis of the occurrence of twist in the case of individual boards revealed significant differences depending on their radial position. Earlier twist development based on a linear correlation of RTW and MC was confirmed in the case of boards located near the pith. Twist onset at a MC of $31.5 \%(\mathrm{CV}=6.1 \%)$ was determined in the case of boards located within the first ten growth rings, whereas boards from the circumference of logs did not start to twist until $\mathrm{MC}$ dropped to $23.8 \%(\mathrm{CV}=7.0 \%)$. Simple regression analysis 
EJWWP422_source.doc

confirmed the significant dependency of twist development on the radial position of the tested boards (Fig. 4), and has a high similarity to the FSP trend in the same direction (Fig. 2d). Earlier twist development in the case of boards from the innerwood, with regard to their MC, can be partially ascribed to the lower rigidity and strength properties of juvenile wood, located close to the pith, which was confirmed by other studies of the same material (Straže and Gorišek 2000). Additionally, due to the lower drying rate and consequently smaller MC gradient, less restrained shrinkage of the wood can be expected in the case of boards located close to the pith. On the other hand, in the case of boards from the sapwood a higher drying rate with a greater MC gradient increased the probability of higher drying stress and more restrained material shrinkage, which, with additional higher rigidity, decreased twist development to a lower MC. Related studies (Stevens 1963; Mackay 1973) confirmed a similar impact of the drying rate on the shrinkage behaviour of wood during drying.

\subsection{Analysis of final twist}

In the case of all investigated boards, the largest twist occurred at the end of the drying process, when the lowest $\mathrm{MC}$ values were reached $\left(\mathrm{MC}_{\mathrm{end}}=5.0 \%, \mathrm{CV}=\right.$ $6.2 \%$ ). Boards located close to the pith had a mean twist angle of $17 \%$, which decreased rapidly with distance from the pith, reaching an almost constant value, between 1 and $3 \% \mathrm{~m}$, at a radius of $70 \mathrm{~mm}$ (Fig. 5). A comparable amount of twist and its radial tendency was also shown for conifer species in related experimental studies (Balodis 1972; Shelly et al. 1979; Johansson et al. 2001).

Stepwise regression analysis was performed in order to investigate to what extent the determined material properties influence the twist magnitude. Stepwise regression analysis is a good tool since co-linearity between the parameters is taken into account. Using this method, $79.6 \%$ of the twist variation at the end of the drying process $\left(\mathrm{MC}_{\mathrm{end}}=5.0 \%, \mathrm{CV}=6.2 \%\right)$ is explained in the resulting governing equation of step 3 (the constant was excluded from the model, $\mathrm{p} \leq 0.05$ ) (Eq. 7):

$$
T W=0.15 \frac{1}{r}+0.48 \cdot G A-9.35 \cdot \alpha_{T}[\circ / m]
$$

where:

$r=$ distance from the pith [m], 
$\mathrm{GA}=$ mean grain angle of the drying board $\left[{ }^{\circ}\right]$ and

$\alpha_{T}=$ tangential shrinkage coefficient $[\% / \%]$.

Ring curvature was confirmed as the most important variable, explaining more than $67.4 \%$ of the final twist (Fig. 5). The tangential shrinkage coefficient explained an additional $10.2 \%$ of the experimental twist variability, whereas the spiral grain angle contributed $2.0 \%$ (Fig. 6). The large variation of GA close to the pith is presumably due to the fact that the GA values were based on the entire length of the cleaved lamella. Many studies on twist, using statistical modelling, have indicated the significant dependency of twist on ring curvature and GA (Forsberg and Warensjö 2001; Johansson et al. 2001). Like in the cited studies, the authors are in doubt regarding the impact of tangential shrinkage on the amount of twist. This impact needs to be additionally researched using a more accurate measuring procedure, neutralizing the influence of ring curvature. Taking into account the observed differences in the radial direction (Fig. 2b), the suspected influence of the GA gradient on the amount of twist was also analysed. No significant impact of the GA gradient was confirmed in the case of any radial position of the boards, as was concluded by Forsberg and Warensjö (2001), which therefore does not support the findings by Ormarsson (1995). Ormarsson's simulations of the amount of twist confirmed that a more rapid reduction of the grain angle towards the cambium causes less twisting of the wood.

\subsection{Modelling of twist during drying}

The amount of twist which may occur during drying can, to some extent, be predicted on the basis of its relationship to some determined material characteristics of the boards (Figs. 2, 3, and 4). Based on well-oriented thin and short drying boards, a simple analytical solution can be used to model twist during drying. The Stevens and Johnston model (1960) was tested on the data using the relation (Eq. 8):

$$
T W=\frac{l}{r} \cdot \frac{2 \cdot G A \cdot \varepsilon_{T}^{,}}{\left(1+\varepsilon_{T}^{,}\right)}
$$

In this formula: $\mathrm{TW}=$ twist is measured in degrees, $1=$ length [m], GA $=$ mean spiral grain angle of the drying specimen $\left[{ }^{\circ}\right], \varepsilon^{\prime}{ }_{T}=$ realized tangential shrinkage, calculated from FSP with the use of a shrinkage coefficient $\left(\alpha_{\mathrm{T}}\right)$, and $\mathrm{r}$ is the radial position of the drying specimen in the $\log [\mathrm{m}]$. 
EJWWP422_source.doc

The model can generally provide a good prediction of the measured twist of boards at any radial position within the whole $\mathrm{MC}$ range, with the smallest deviation at greater distances from the pith and at low $\mathrm{MC}\left(\mathrm{R}^{2}>0.44\right.$; Fig. 7, 8). The development of the calculated twist follows the dependence of the average FSP on the distance from the pith, presented by the regression model (Fig. 2d). The used medium decrease of GA in the radial direction (Fig. 2a; Eq. b: GA = $0.018 \mathrm{r}+4.5)$ has the greatest impact on the calculated values close to the pith, where GA orientation (positive or negative) is also important. The use of the highest GA gradient (Fig. 2a; Eq. c: $G A=-0.04 r+5.2$ ), inducing a negative GA at the logs' circumference, would also lead to a negative calculated twist at a greater distance from the pith. On the other hand, two opposite factors actually influence the realized tangential shrinkage: the lower tangential shrinkage coefficient $\left(\alpha_{\mathrm{T}}\right)$ close to the pith (Fig. 2c), and the higher FSP at the same location (Fig. 2d). For this reason insignificant effect is ascribed to the influence of tangential shrinkage on the twist of drying boards. Nevertheless, ring curvature, i.e., the distance from the pith, has, similarly to the regression analysis results (Eq. $4)$, the most pronounced effect on the calculated twist values.

\section{Conclusion}

The results of this research confirmed the effect of different predictive strengths of the tested material properties on twist modelling during drying of sawn wood of Norway spruce. Annual growth ring curvature had the greatest impact on the final amount of twist, followed by grain angle and tangential shrinkage. Twisting of the dried boards generally developed at a moisture content corresponding to the fibre saturation point, and increased proportionally to the reduction in average moisture content, being most pronounced in the case of boards close to the pith. A significant reduction of the fibre saturation point for boards close to the bark also delayed the development of twist. Earlier twist appearance, with regard to wood moisture content and drying time, was determined in the case of boards from the inner part of logs, where also the highest final twist was observed. Some researchers confirmed that the higher drying rate presumably increased the MC gradient and drying stress, and therefore restrained shrinking and twisting of boards from the sapwood area (Mackay 1973; Price and Koch 1980; Pang and Pearson 2004). It is believed that future modelling of the twist of boards during 
drying could be improved by including additional material properties such as MC gradient and drying stress.

\section{References}

Arganbright DG, Venturino JA, Gorvad M (1978) Warp reduction in young-growth Ponderosa pine studs dried by different methods with top-load restraint. For. Prod. J 28(8):47-52 Bäckström M, Johansson M (2006) Analytical model of twist in Norway spruce (Picea abies) timber. Scand. J. For. Res. 21:54-62

Bäckström M, Kliger R (2006) Restraining moisture related twist in timber structures. Holz RohWerkst 64:235-242

Balodis V (1972) Influence of grain angle on twist in seasoned boards. Wood Sci. 5:44-50 Booker RE (2005) Geometric model to predict twist in unrestrained boards. Wood Sci. Technol 39: $269-289$

Chong ET, Fogg PJ (1989) Differences in moisture content and shrinkage between innerwood and outerwood of two shortleaf pine trees. For. Prod. J. 39(3):13-18

Cown DJ, McCounchie DL (1983) Radiata pine wood properties survey (1977-1982). FRI Report, New Zeland Forest Service, 50p.

Danborg F (1994) Spiral grain in plantation trees of Picea abies. Can. J. For. Res.24:1662-1671

Donaldson LA, Burdon RD (1995) Clonal variation and repeatability of microfibril angle in Pinus Radiata. N. Zealand J. of For. Sci. 25:164-174

Feist WC, Tarkow H (1967) A new procedure for measuring fiber saturation points. For. Prod. J. 17(10):65-68

Forsberg D, Warensjö M (2001) Grain angle variation: A major determination of twist in sawn Picea abies Karst. Scand. J. For. Res. 16:269-277

Frühwald E (2007) Effect of high temperature drying and restraint on twist of Norway spruce. Drying Technology 25:489-496

Frühwald E (2006) Improvement of shape stability by high-temperature treatment of Norway spruce. Effect of drying at $120^{\circ} \mathrm{C}$ with and without restraint of twist. Holz Roh- Werkst 64:24-29 Gorišek Ž, Straže A, Pervan S (2004) Juvenile wood in spruce (Picea abies Karst.) - limitation of use. International conference - Wood in the construction industry Proceedings (ed. Jambreković V.), Zagreb, 92p

Gorišek Ž, Straže A (2005) Influence of wood structure on the warping quality in Norway spruce (Picea abies Karst.) during kiln drying. International conference - Wood in the construction industry Proceedings (ed. Jambreković V.), Zagreb, 124p

Gorišek Ž, Straže A, Gornik-Bučar D, Bučar B (2006) Influence of some anatomical and physical properties of wood on warp during kiln drying of spruce (Picea abies Karst.) and silver fir (Abies alba Mill.). COST E40 Proceedings (ed. Teischinger A.), Biel:67-72

Harris JM, Meylan BA (1965) The influence of microfibril angle on longitudinal and tangential in Pinus Radiata. Holzforschung 19:144-153

Harris JM (1977) Shrinkage and density of radiata pine compression wood in relation to its anatomy and mode of formation. N. Zealand J. of For. Sci. 7:91-106

Johansson M, Perstorper M, Kliger R (2001) Distortion of Norway spruce timber. Part 2:

Modelling twist. Holz Roh- Werkst 59:155-162

Kellogg RM, Wangaard FF (1969) Variation in the cell-wall density of wood. Wood Fiber 1:180204

Kliger R, Bengtsson C, Johansson M (2005) Comparison between HT and LT-dried spruce timber in terms of shape stability and dimensional stability. Holzforschung 59:647-653

Mackay JFG (1973) The influence of drying conditions and other factors on twist and torque in pinus radiata studs. Wood Fiber. 4:264-271

Milota MR. (2000) Warp and shrinkage of hem-fir stud lumber dried at conventional and high temperature drying. For. Prod. J. 50(11/12):79-84

Ormarsson S (1995) A finite element study of the shape stability of wand timber subjected to the moisture variations. Report TVSM-3017, Lund Univ. of Tech., 91p.

Ormarsson S, Dahlblom O, Petersen H (1998) A numerical study of the shape stability of sawn timber subjected to moisture variation. Part 1: Theory. Wood Sci. Technol.32:325-334

Ormarsson S, Dahlblom O, Petersson H (1999) A numerical study of shape stability of sawn timber subjected to moisture variation. Part 2: Simulation of drying board. Wood Sci. Technol. $33: 407-423$ 
EJWWP422_source.doc

Pang S, Pearson H (2004). Experimental investigation and practical application of superheated steam drying technology for softwood timber. Drying Tech. 22(9):2079-2094

Pang S, Simpson IG, Haslett AN (2001) Cooling and steam conditioning after high-temperature drying of Pinus radiata board: Experimental investigation and mathematical modelling. Wood Sci. Technol. 35:487-502

Perstorper M, Johansson M, Kliger R, Johansson G (2001) Distortion of Norway spruce timber. Part 1: Variation of relevant wood properties. Holz Roh- Werkst 59:94-103

Perstorper M, Pellican PJ, Kliger R, Johansson G (1995) Quality of timber products from Norway spruce.Part 1: Optimization, key variables and experimental study. Wood Sci. Technol. 29:157170

Price EW, Koch P (1980) Kiln time and temperature affect shrinkage, warp and mechanical properties of southern pine lumber. For. Prod. J. 47(1):41-47

Sandland MK, Tronstad S (2001) Possibilities to control deformationsin wood during drying to meet the requirements from timber end-users. COST E15 Proceedings (ed. Welling J.), Helsinki, $10 \mathrm{p}$

Sepulveda P (2001) Measurement of spiral grain with computed tomography. J. Wood Sci. 47:289-293

Shelly JR, Arganbright DG, Birnbach M (1979) Severe warp development in young-growth Ponderosa Pine studs. Wood Fiber 11:50-56

Stamm AJ (1971) Review of nine methods for determining the fiber saturation points of wood and wood products. Wood Sci. 4:114-128

Stevens WC, Johnston DD (1960) Distortion caused by spiral grain. Timber Tech. 68:217-218 Stevens WC (1963) The transverse shrinkage of wood. For. Prod. J. 13:386-389

Straže A, Gorišek Ž (2000) Density in mechanical properties of the juvenile and adult wood of Norway spruce wood (Picea abies Karst.) and silver fir (Abies alba Mill.). Wood (Les) 52(6):185190

Thiam M, Milota MR, Leichti RJ (2002) Effect of high-temperature drying on bending and shear strengths of western hemlock lumber. For. Prod. J. 52(4):64-68

Vorreiter L (1963) Fasersättigungsfeuchte und höchste Wasseraufnahme der Hölzer.

Holzforschung 17:139-146

Warensjo M, Rune G (2004) Effect of compression wood and grain angle on deformations on studs from 22-year-old Scots pine trees. Scand. J. For. Res. 19(5):48-54 


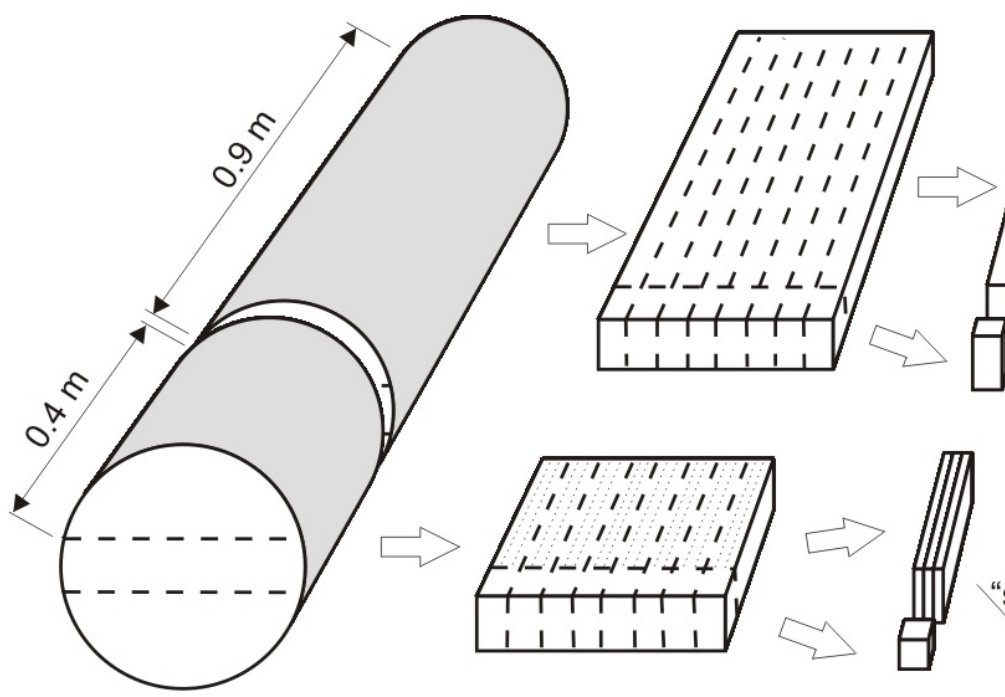

Basic properties

$\left(\varepsilon_{\mathrm{T}}, \alpha_{\mathrm{T}}, \mathrm{FSP}\right)$ :

$18 \times 18 \times 5 \mathrm{~mm}$

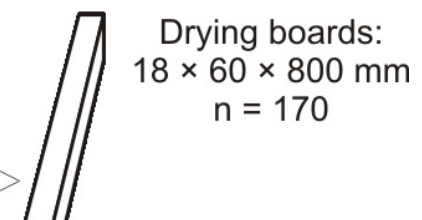

Drying boards:

$\mathrm{n}=170$

\section{Slices for $\mathrm{MC}_{\mathrm{i}}$}

Bundle of 3 lamellas for GA and $\mathrm{Ga}_{\text {gradient: }}$ $3 \times 60 \times 350 \mathrm{~mm}$ "sawn at $6 \mathrm{~mm}$ distance"

GA determination:

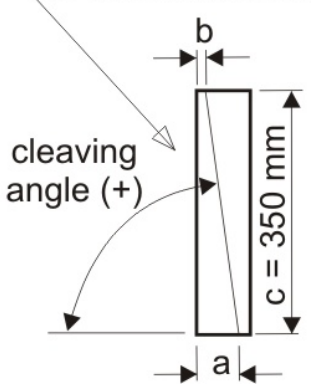

Figure 1 Sawing pattern for drying boards and specimens for basic wood properties of Norway spruce (Picea abies Karst.).
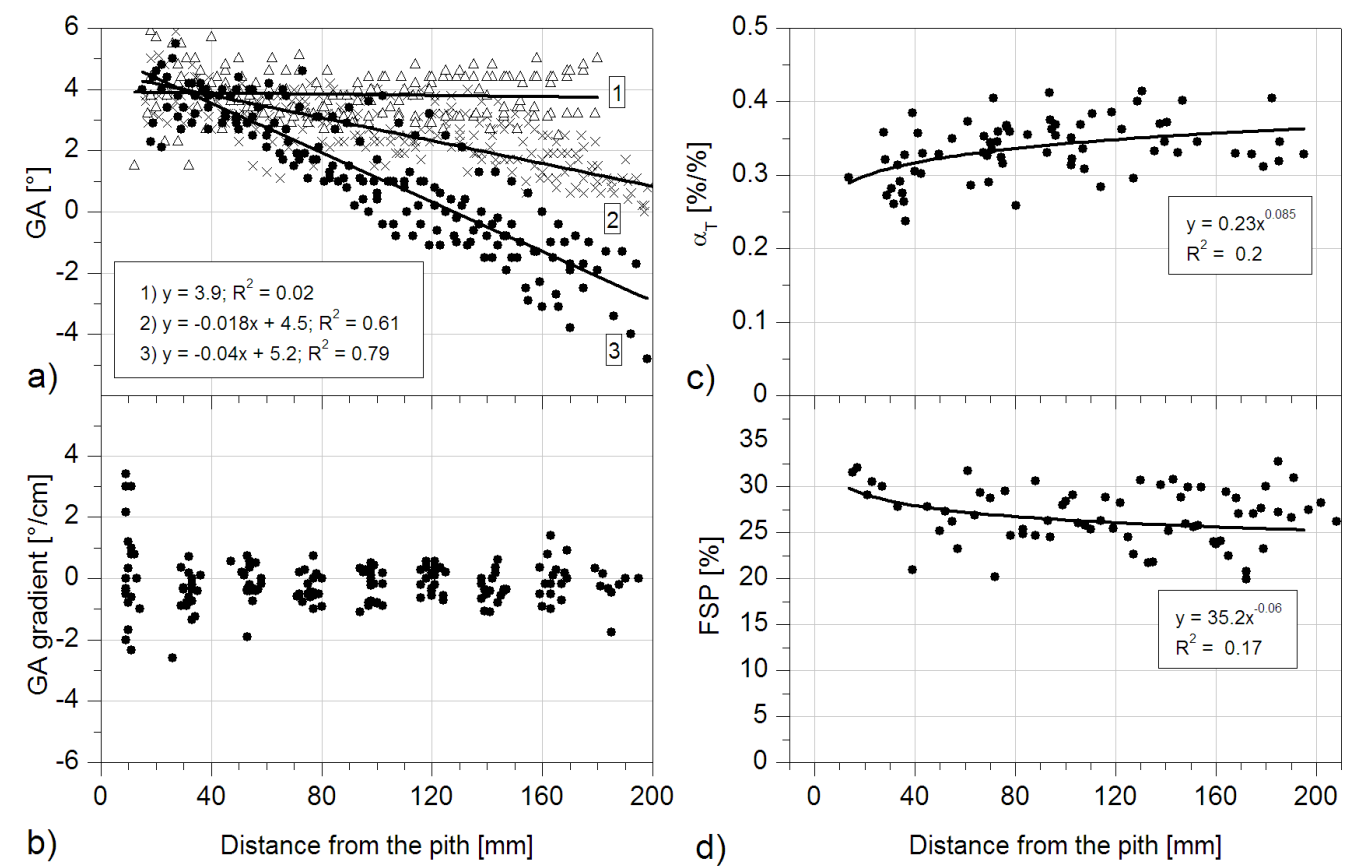

Figure 2 Variation of wood properties in radial direction: a) Grain angle (GA), b) Grain angle gradient, c) Tangential shrinkage coefficient $\left(\alpha_{\mathrm{T}}\right)$ and d) Fibre saturation point (FSP). 


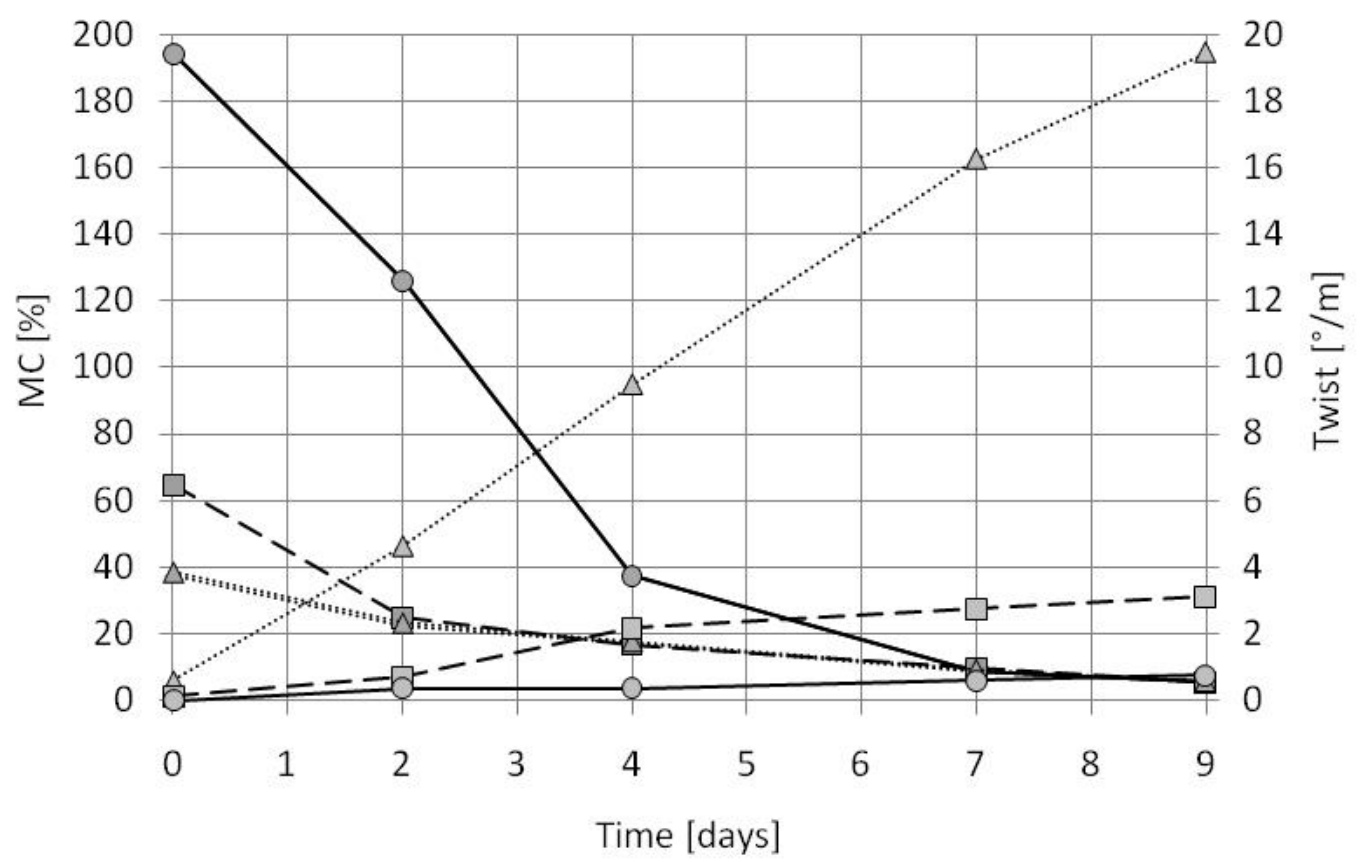

Figure 3 Average drying curves (left y-axis) and twist appearance (right y-axis) in kiln dried boards from sap- $(-)$, intermediate- (- - -) and inner-wood ( $\cdots)$.

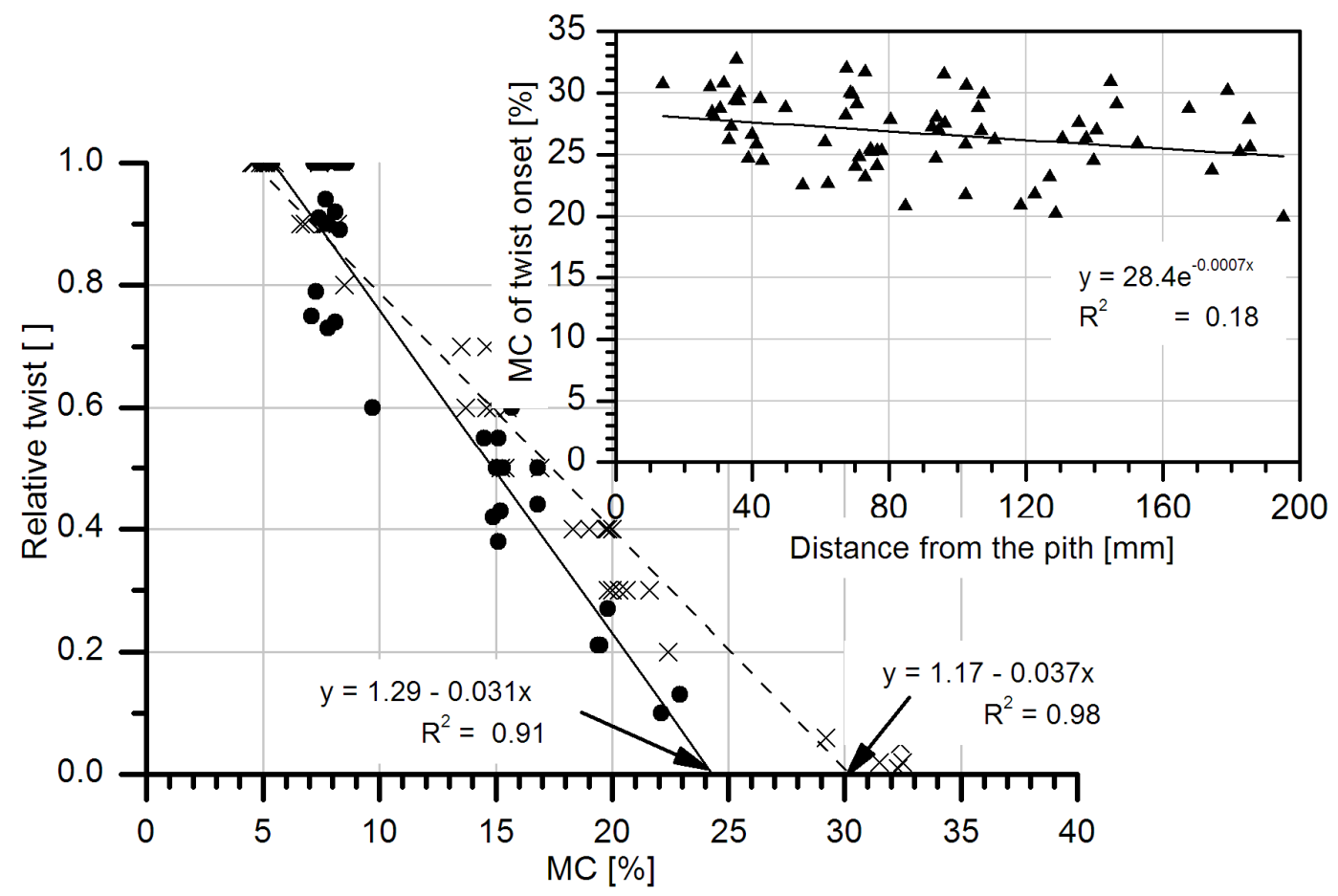

Figure 4 Impact of MC on the outset and formation of twist (represented by relative twist; Eq. 6) in kiln dried boards from sapwood $(\bullet ; n=45 ;-$ linear regression $)$ and inner-wood $(\times ; n=56 ; \cdots$ linear regression). 


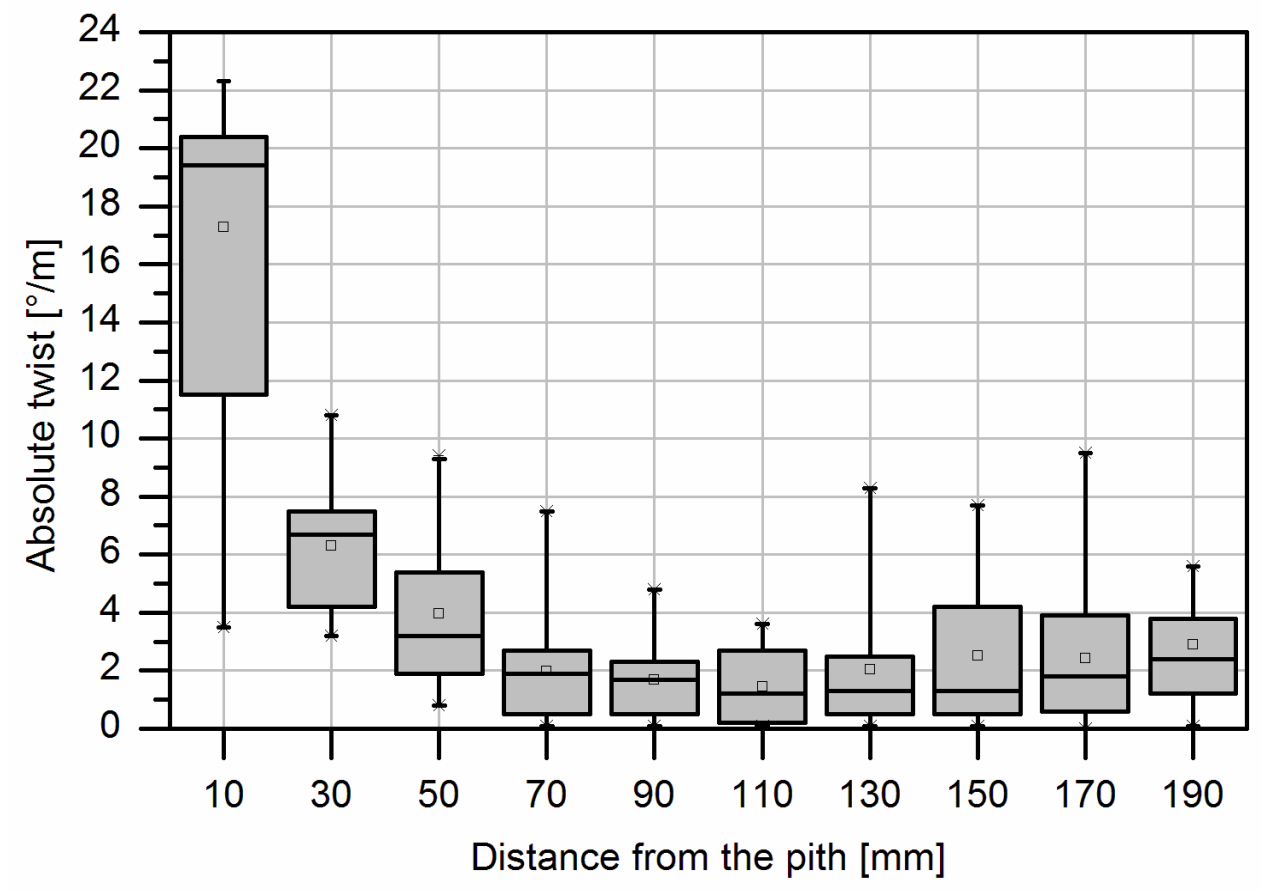

Figure 5 Dependency of absolute twist in boards on radial position in log at the end of drying process.

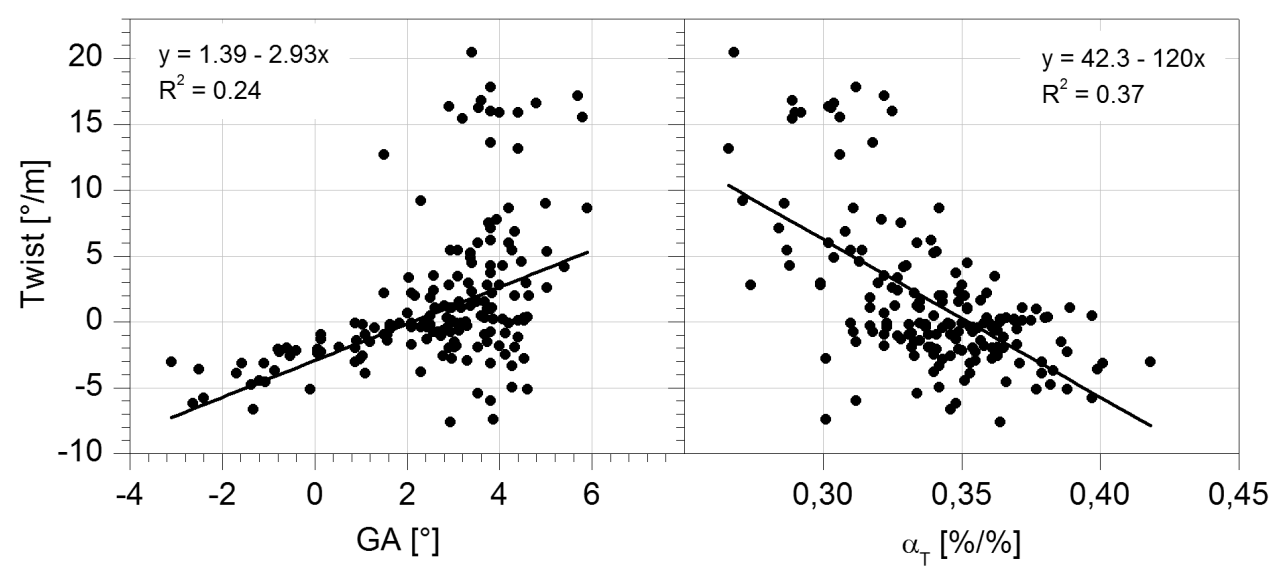

Figure 6 Dependency of final twist amount on grain angle (GA) and tangential shrinkage coefficient $\left(\alpha_{\mathrm{T}}\right)$ of dried boards. 


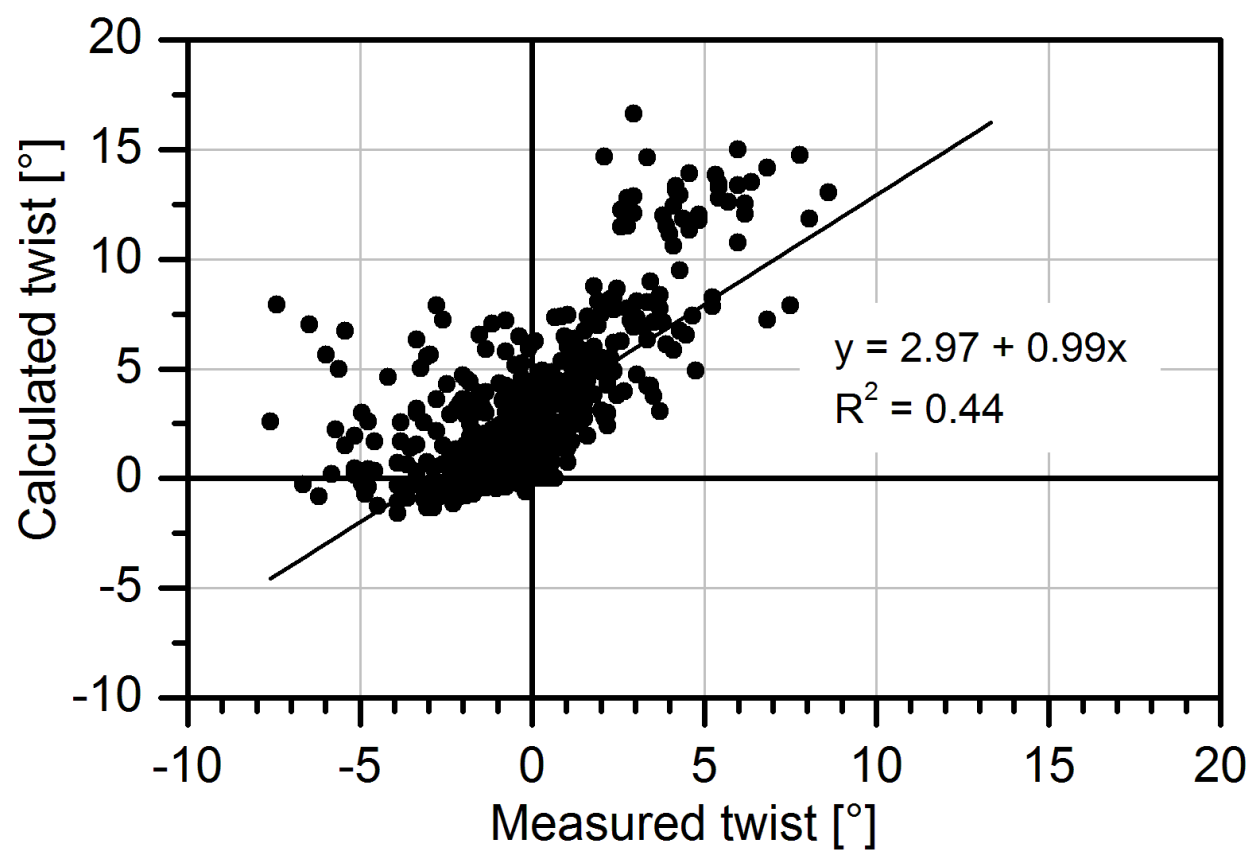

Figure 7 Twist predicted with Stevens and Johnston model, cf. Eq. (7) in whole hygroscopic range compared to measured values.

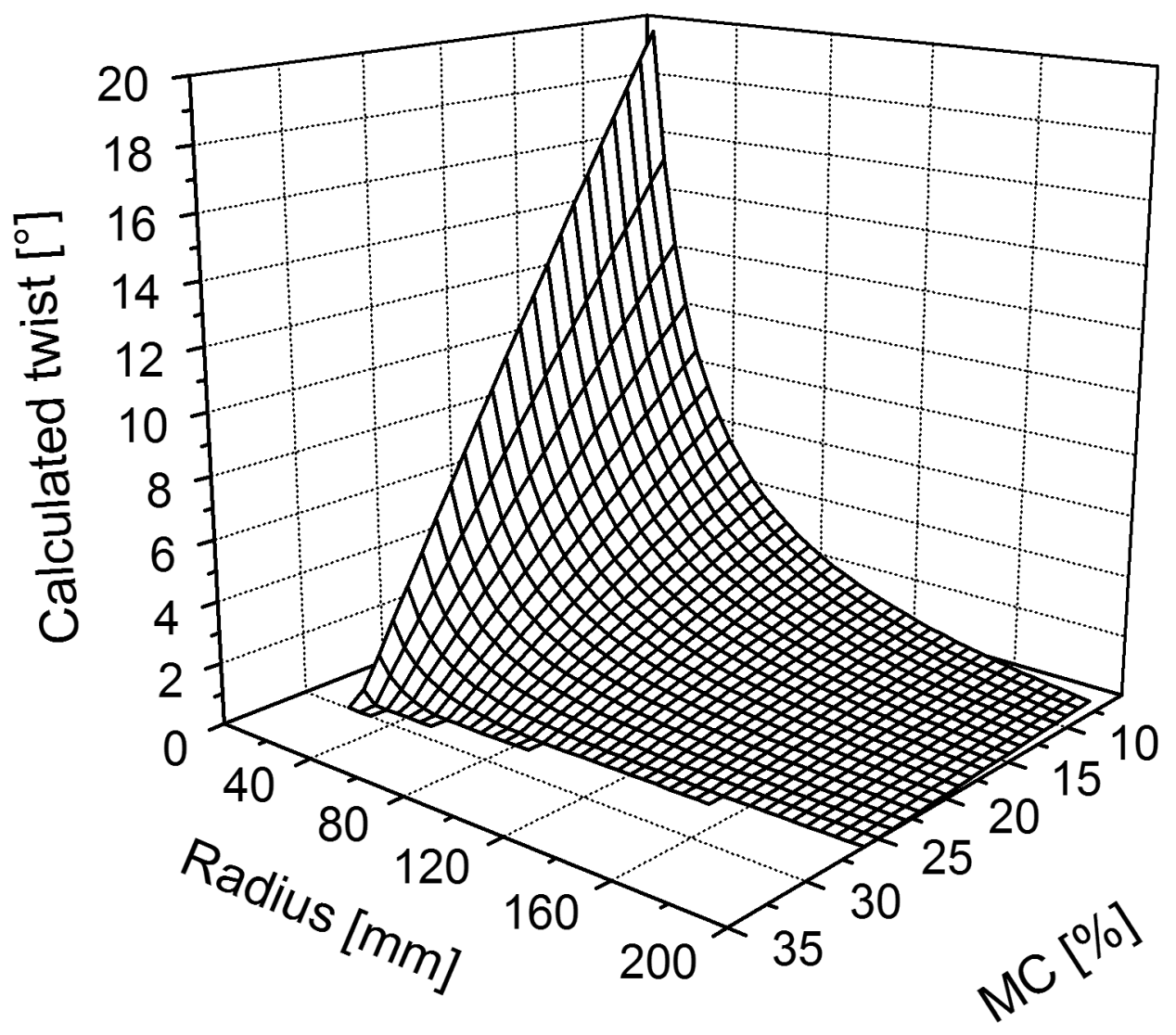

Figure 8 Twist predicted with Stevens and Johnston model during kiln drying of boards from various radial positions in the $\log$. 
EJWWP422_source.doc

Abb. 1

Schnittplan für die Bretter für den Trocknungsversuch und für die Prüfkörper zur Bestimmung der Materialeigenschaften des Fichtenholzes (Picea abies Karst.)

Abb. 2

Veränderung der Holzeigenschaften in radialer Richtung: a) Faserwinkel (GA), b) Änderung des Faserwinkels im Brett, c) Tangentiales Schwindmaß $\left.\left(\alpha_{\mathrm{T}}\right), \mathrm{d}\right)$ Fasersättigung (FSP)

Abb. 3

Mittlere Trocknungskurven (linke y-Achse) und Verdrehung (rechte y-Achse) technisch getrockneter Bretter aus dem Splintholzbereich (-), dem mittleren -(- -) und dem marknahen ( $\cdots)$ Bereich

Abb. 4

Einfluss der Holzfeuchte (MC) auf den Beginn und die Entwicklung der Verdrehung (relative Verdrehung, Gleichung 6) von technisch getrockneten Brettern aus dem Splintholzbereich $(\bullet ; n=45 ;-$ lineare Regression) und dem marknahen Bereich $(\times ; n=56 ; \cdots$ lineare Regression $)$.

Abb. 5

Absolute Verdrehung der Bretter am Ende der Trocknung in Abhängigkeit vom Markabstand

Abb. 6

Abhängigkeit der Verdrehung am Ende der Trocknung vom Faserwinkel (GA) und dem tangentialen Schwindmaß $\left(\alpha_{\mathrm{T}}\right)$

Abb. 7

Vergleich der rechnerisch ermittelten Gesamtverdrehung nach dem Modell von Stevens und Johnston (Gleichung 7) mit den Versuchswerten

Abb. 8

Verdrehung der Bretter im Verlauf der technischen Trocknung in Abhängigkeit vom Markabstand rechnerisch ermittelt mit Modell von Stevens und Johnston 